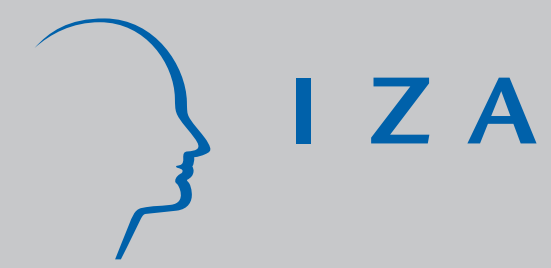

IZA DP No. 7786

Old-Age Government Transfers and the Crowding Out of Private Gifts: The $\mathbf{7 0}$ and Above Program for the Rural Elderly in Mexico

Catalina Amuedo-Dorantes

Laura Juarez

November 2013 


\title{
Old-Age Government Transfers and the Crowding Out of Private Gifts: The 70 and Above Program for the Rural Elderly in Mexico
}

\author{
Catalina Amuedo-Dorantes \\ San Diego State University \\ and IZA
}

Laura Juarez

Banco de Mexico

\author{
Discussion Paper No. 7786 \\ November 2013
}

\author{
IZA \\ P.O. Box 7240 \\ 53072 Bonn \\ Germany \\ Phone: +49-228-3894-0 \\ Fax: +49-228-3894-180 \\ E-mail: iza@iza.org
}

Any opinions expressed here are those of the author(s) and not those of IZA. Research published in this series may include views on policy, but the institute itself takes no institutional policy positions. The IZA research network is committed to the IZA Guiding Principles of Research Integrity.

The Institute for the Study of Labor (IZA) in Bonn is a local and virtual international research center and a place of communication between science, politics and business. IZA is an independent nonprofit organization supported by Deutsche Post Foundation. The center is associated with the University of Bonn and offers a stimulating research environment through its international network, workshops and conferences, data service, project support, research visits and doctoral program. IZA engages in (i) original and internationally competitive research in all fields of labor economics, (ii) development of policy concepts, and (iii) dissemination of research results and concepts to the interested public.

IZA Discussion Papers often represent preliminary work and are circulated to encourage discussion. Citation of such a paper should account for its provisional character. A revised version may be available directly from the author. 
IZA Discussion Paper No. 7786

November 2013

\title{
ABSTRACT
}

\section{Old-Age Government Transfers and the Crowding Out of Private Gifts: The 70 and Above Program for the Rural Elderly in Mexico}

\begin{abstract}
We estimate the crowding out of private transfers caused by 70 y Más - a public assistance program for the rural elderly in Mexico for whom family support is an important source of income. Using data from the Mexican Income and Expenditure Survey and a triple difference approach, we find that the program crowds out private gifts by 37 percent, and it does so mostly by reducing the probability of receiving domestic remittances. As a result, the nonlabor income of beneficiaries increases by less than their government transfers. Thus, by reducing their private support to the elderly, domestic donors are dampening the effect of the program, although not completely neutralizing it.
\end{abstract}

JEL Classification: $\quad H 3, H 55, J 14$, J18

Keywords: old-age government transfers, crowding-out, remittances, Mexico

Corresponding author:

Catalina Amuedo-Dorantes

Department of Economics

San Diego State University

San Diego, CA 92182

USA

E-mail: camuedod@mail.sdsu.edu 


\section{Introduction}

In 2007, the Mexican government started 70 y Más (which translates as 70 and Above) -a non-contributory pension program that paid about 40 USD per month to individuals age 70 and older residing in localities with up to 2,500 inhabitants, the smallest in the country. ${ }^{1}$ The program was implemented with the explicit purpose of increasing the income of beneficiaries, many of whom might not qualify for social security benefits due to the low coverage of contribution-based pension systems in rural areas. ${ }^{2}$ Yet, the attainability of its goal partially depends on whether this government transfer crowds out the support that the elderly receive from their families.

In this paper, we estimate the crowding out effect of 70 y Más on the remittances received by the rural elderly from both domestic and international donors -a relevant aim for a number of reasons. First, as noted by Aguila et al. (2011), family support is an important income source for the elderly in Mexico. In our data, about 32 percent of individuals age 70 and older in localities with less than 2,500 inhabitants reported receiving remittances on a monthly basis in 2006, the year before the 70 y Más program was implemented, and on average those monetary inflows represented about 57 percent of their individual total income. $^{3}$ Thus, the response of family support is key to assess the redistribution actually achieved by the program. Second, the 70 y Más program quickly expanded to larger localities, reaching 3.5 million beneficiaries in 2012 (Guthrie, 2012) and effectively becoming the first universal pension program in Mexico. The magnitude of the program underscores the relevance of estimating the impacts of such a large-scale intervention. Third, age-based non-contributory pensions have become increasingly popular in other developing countries, especially in Latin America. Levy and Schady (2013) estimate that governments in this region spent an average of 0.56 percent of GDP on these programs in 2011 and, more importantly, the cost is not likely to go down anytime soon as governments face ongoing 
political pressure to expand these programs' budgets and coverage. For all the aforementioned reasons, gauging the extent of crowding out, if any, is relevant to determine whether the large, and potentially increasing, public resources transferred to the elderly through programs like 70 y Más are enjoyed by the intended beneficiaries or are benefiting other age groups. ${ }^{4}$

Whereas the empirical literature on crowding out is large, few previous studies have focused on the crowding out of private transfers caused by similar age-based transfer programs for the elderly. For instance, Jensen (2004) finds that an age-conditioned pension in South Africa reduces private transfers by about 30 percent. For Mexico, Juarez (2009) estimates the effect of an earlier state cash transfer program for individuals age 70 and older in the state of Distrito Federal (hereafter DF), which is part of the metropolitan area of Mexico City, on private transfers and estimates a crowding out of 86 percent. Our paper contributes to this literature by providing evidence for the Mexican rural elderly, who differ from the potential beneficiaries of the DF program in various regards: (a) they have lower incomes, (b) they have lower participation rates in social security, and (c) they display a greater dependence on remittances than their urban counterparts.

Our contribution is particularly relevant given that, despite the size of the program and the recent expansion implemented by the newly elected Mexican president, the current evidence on 70 y Más is rather scarce. As part of the early impact evaluation of the program, Galiani and Gertler (2009) compare the economic outcomes of households with at least one individual age 70 to 74 in localities with less than 2,500 inhabitants in which the program was originally operating, to those of similar households in localities with 2,500-3,300 inhabitants, which were not initially participating in the program. They find that private transfers received by qualifying households increased by 17.5 pesos per month after the program started. However, the applicability of their findings in a broader context is limited 
because their pilot sample, designed specifically for the initial evaluation of the program, provides evidence only for individuals close to age and locality size eligibility cutoffs and it is not nationally representative. Additionally, the rapid expansion of the program potentially compromises their estimation strategy because localities just above the 2,500 inhabitants threshold were incorporated to the program in 2008, as their second round of data was being collected.

To improve on these limitations, our analysis relies on a sample of individuals age 55 and older from the Mexican Income and Expenditure Survey (Encuesta Nacional de Ingresos y Gastos de los Hogares, ENIGH) -a nationally representative cross section dataset collected every two years by the Mexican Institute of Statistics (Instituto Nacional de Estadística, Geografía e Informática, INEGI). We use data from the 2006 and 2008 rounds, before and after the implementation of 70 y Más. Our empirical strategy compares the remittances received by individuals age 70 and older, in localities with less than 2,500 inhabitants, our treatment group, with those received by same-age individuals in localities with more than 100,000 inhabitants, where the program was not operating in 2008. We also add to previous work on the program by looking separately at its impact on the probability of receiving remittances (extensive margin) and on the amounts for individuals receiving them (intensive margin). To account for any other changes affecting older adults in treated localities that cannot be attributed to the program, we include individuals 55-69 years old, because they do not qualify for 70 y Más, regardless of the locality they live in. Additionally, we control for the relevant individual and household characteristics, together with municipal fixed-effects to account for other differences between older adults residing in treated versus control localities.

We find that the program crowded out total remittances by 37 percent. This effect was mostly driven by a reduction of 7.8 percentage points (or 31 percent) in the likelihood of receiving domestic remittances. The program had no statistically significant effect on either 
the probability of receiving international remittances, or on the amounts of either domestic or international remittances received if positive. Thus, the program crowded out domestic remittances only, and it did so at the extensive margin. These results suggest either that the motives driving domestic versus international remittances are different, or that domestic donors are better informed about the program than those living abroad. After estimating the program effects by gender, we find that the overall crowding out was much greater for women than men.

To confirm the non-existence of pre-program trends driving our results, we first conduct a placebo test using only data from before the introduction of the 70 y Más program. Subsequently, to address any concerns regarding the comparability of small (treated) and larger (control) localities, we perform a series of robustness checks using alternative definitions of the treatment and control groups that, in the extreme, include all types of locality sizes. Additionally, because since 2001 some Mexican states implemented their own non-contributory pension schemes for elderly individuals (Aguila et al. 2011), we also perform the analysis excluding the states that did so at the same time as 70 y Más. Lastly, we complement our main analysis by estimating the crowding out effect at the household level. All these tests confirm the reliability of our findings.

To conclude, we estimate the increase in government transfers following the implementation of the program and compare it to the increase in non-labor income experienced by age-qualifying individuals in treated localities between 2006 and 2008. Our estimates reveal that on average non-labor income increased by 15 percent less than government transfers for the full sample, and by 52 percent less for those whose non-labor income is below the mean. This implies that domestic donors were mitigating the income redistribution intended by the program, particularly for seniors with lower incomes. The magnitude of the crowding out effect is roughly comparable the estimate in Jensen (2004), 
but smaller than the one in Juarez (2009) for DF. Our smaller estimates may be due to the fact that the rural elderly in Mexico receive a higher fraction of their private transfers from abroad, compared to their urban counterparts in DF, and international remittances are, precisely, the least responsive transfers to the program. In that regard, our estimates provide a lower bound for the crowding out effect that the program could have nationwide as it expands to larger, more urban localities, in which the elderly receive most of their private support from domestic donors.

\section{Conceptual Framework}

The theoretical literature considers two main motives for private transfers: altruism (e.g. Becker, 1974) and exchange (e.g. Bernheim et al., 1985). Altruistic transfers occur because the donor cares about the utility of the recipient. Therefore, a public transfer paid to the elderly may crowd out private transfers sent altruistically as the recipients enjoy higher incomes. ${ }^{5}$ Alternatively, transfers can also take place in exchange for provided services, such as the care of children or the oversight of property. Public transfers may also crowd out these transfers if the elderly reduce their supply of such services and the donor's demand is elastic (Cox, 1987). Conversely, if the donor's demand for services is inelastic, public transfers could actually result in larger private transfers paid to the elderly in exchange for provided services, which would reinforce the income redistribution goals of the government. ${ }^{6}$

For rural households, like the ones targeted by the 70 y Más program, international remittances are an important fraction of the total private transfers they receive. Along with altruism and exchange, the literature on international remittances recognizes other motives for sending money back home, such as the wish to invest in physical or financial assets to self-insure or to earn a higher return (e.g. Durand et al., 1996), or the desire to maintain access to household resources, such as an inheritance (e.g. Lucas and Stark, 1985; Gubert, 2002; Amuedo-Dorantes and Pozo, 2006). In contrast to private transfers motivated by 
altruistic or exchange motives, those motivated by these other purposes may not necessarily be crowded out by public transfers.

In what follows, we estimate whether a public transfer crowds out the domestic and international remittances received by the rural elderly. These two types of transfers may be crowded out to different degrees due to differences in donors' motivation or information about the program. For instance, a public transfer may not crowd out international remittances, as much as domestic ones, if the former are more likely to be sent to earn a higher return than the latter, or if international donors have less information than domestic ones about the existence and amount of the public transfer received by their elderly.

\section{The 70 y Más Program}

The 70 y Más program was a federal program for the rural elderly that paid a cash transfer of 80 USD every two months to individuals age 70 and older in qualifying localities. Until 2011, the transfer was exclusively conditioned on age and locality of residence, so it was not means-tested, not taxable and did not depend on previous contributions to the Mexican social security system. As a result, in the first four years of the program, eligibility was not correlated with past or current labor and saving decisions, or with unobservable factors associated to individual income or the receipt of private transfers.

The program started in 2007, covering all age-eligible individuals living in localities with up to 2,500 inhabitants, and reached about a million beneficiaries by the end of that year. According to a 2008 Program Performance Report, this corresponds to a 100 percent coverage rate in those localities. ${ }^{7}$ The program expanded quickly thereafter. On December 31, 2007, it was extended to localities up to 20,000 inhabitants, and the number of beneficiaries grew to 1.9 million. In 2009, localities with up to 30,000 inhabitants were included in the program. Finally, in January 2012, the remaining localities - those with more than 30,000 inhabitants - were also incorporated. ${ }^{8}$ The rollout of the program responds to the 
low participation in the social security system observed in small, rural localities, which results in low pension receipt for the elderly living there. The program also promotes the use of health care services provided by Seguro Popular (Popular Insurance) among its beneficiaries. $^{9}$

To receive the transfer from 70 y Más, an individual must sign up for the program and present an official ID, proof of age (birth certificate or unique population id number: CURP), and a utility bill to verify her address. In addition, the applicant must not be a beneficiary of the Oportunidades program and, if she is, she must cancel her participation in that program to receive benefits from 70 y Más. ${ }^{10}$ The Ministry of Social Development (SEDESOL) organizes program information and enrollment campaigns in qualifying localities to facilitate the registration of eligible individuals. This ensures high participation rates, as mentioned before. In addition, according to a 2010 audit report about the program, about 89 percent of beneficiaries received program payments as scheduled. ${ }^{11}$

As part of an early impact evaluation of the program, Galiani and Gertler (2009) examine the effect of the program on the income, expenditures, savings and time use of beneficiaries by exploiting the discontinuities at the age and locality size eligibility cutoffs. Specifically, they compare the private transfers received in 2009 by households with at least one individual age 70 to 74 in localities with less than 2,500 inhabitants, in which the program was operating, to those received by similar households in localities with 2,500-3,300 inhabitants. They find that private transfers actually increased by 17.5 pesos per month after the program started. However, their sample, which was expressly designed for an initial evaluation of the program, provides evidence only for those around the eligibility cutoffs, and it is not nationally representative. ${ }^{12}$ Additionally, the rapid expansion of the program likely tainted their identification strategy and results because localities with up to 20,000 inhabitants were incorporated to the program in $2008 .^{13}$ As described in the next section, we use a 
different dataset and empirical strategy to address those limitations. We also differentiate between the program's effects on remittance inflows originated nationally, as opposed to internationally, and between the distinct impacts of 70 y Más according to the gender of the recipient.

Non-contributory pension schemes have become increasingly popular in Mexico. In fact, between 2001 and 2011 about 16 out of 32 states implemented their own local program of this type (Aguila et al. 2011). Although many of these state programs also have an age-70 cutoff, they differ from 70 y Más in other eligibility requirements and in their transfer amounts. In fact, some of them cover individuals who were not eligible for the 70 y Más program in 2008. ${ }^{14}$ Thus, as a robustness check, we also carry out the analysis excluding those states that initiated their own transfer programs between 2007 and 2008.

\section{Data and Methodology}

We rely on cross section data from the Mexican Income and Expenditure Survey (Encuesta Nacional de Ingresos y Gastos de los Hogares, ENIGH), a nationally representative survey carried out by the Mexican Statistical Institute (Instituto Nacional de Estadística, Geografía e Informática, INEGI). The first wave of the survey was administered in 1983-1984. Subsequent survey waves were completed in 1989 and, from 1992 onwards, biennially. $^{15}$

We use data from the 2006 and 2008 waves of the ENIGH. The ENIGH collects thorough information on household expenditures and income. Expenditures are reported at the household level, but income from different sources during the past six months, including domestic and international private transfers, are recorded for each individual in the household. ${ }^{16}$ The survey does not have any information on the characteristics of donors. Likewise, it does not have locality identifiers or characteristics. Nevertheless, we observe whether individuals belong to any of the following four groups according to the size of the 
locality they live in: those in localities with less than 2,500 inhabitants, localities with 2,50014,999 inhabitants, localities with 15,000-99,999 inhabitants and localities with 100,000 or more inhabitants.

We focus on individuals at least 55 years old -both before and after the policy change. We deflate all transfer and income variables using the consumer price index, so they are all expressed as monthly average amounts in 2010 pesos. To measure the crowding out of private transfers received by the rural elderly after the program started, we estimate the following two equations by ordinary least squares (OLS):

$\operatorname{Prob}\left(R_{i m}>0\right)=\alpha_{1}+\gamma_{1} D 70_{i} * T_{i} * D 2008_{i}+\gamma_{2} D 70_{i}+\gamma_{3} T_{i}+\gamma_{4} D 2008_{i}+\gamma_{5} D 70_{i} * T_{i}$

$+\gamma_{6} D 70_{i} * D 2008_{i}+\gamma_{7} T_{i}^{*} D 2008_{i}+X_{i} \beta_{1}+\delta_{m}+u_{i m 1}$

$\log \left(R_{i m}\right)=\alpha_{2}+\delta_{1} D 70_{i} * T_{i} * D 2008_{i}+\delta_{2} D 70_{i}+\delta_{3} T_{i}+\delta_{4} D 2008_{i}+\delta_{5} D 70_{i} * T_{i}$

$+\delta_{6} D 70_{i} * D 2008_{i}+\delta_{7} T_{i}^{*} D 2008_{i}+X_{i} \beta_{2}+\delta_{m}+u_{i m 2} \quad$ (for obs. with $\mathrm{R}_{\mathrm{im}}>0$ )

where $R_{i m}$ is the amount of domestic, international or total remittances received by individual $i$ in municipality $m$, depending on the model specification, $D 70_{i}$ is a dummy variable equal to 1 if the individual is at least 70 years old, $T_{i}$ is another dummy variable equal to 1 if the individual lives in a locality treated by the program, and $D 2008_{i}$ is equal to 1 for individuals interviewed in 2008, after the program was implemented. By estimating equations (1) and (2) above, we are able to analyze whether the crowding out effect, if any, is mostly due to a reduction in the probability of receiving such inflows (extensive margin), or to a reduction in the amounts received if positive (intensive margin). ${ }^{17}$

Individuals at least 70 years old in localities with less than 2,500 inhabitants participated in the government program from 2007 onwards. Individuals at least 70 years old in the next group of localities, i.e., those with 2,500-14,999 inhabitants, as well as some in the group of localities with 15,000-99,999 inhabitants, started receiving program benefits in 2008. Finally, age-eligible individuals residing in the largest localities, i.e. those with 
100,000 or more inhabitants, were not eligible for the government transfers in 2008. In our main analysis, age-eligible individuals in the smallest localities (those with less than 2,500 inhabitants) constitute our treatment group $\left(T_{i}=1\right)$, whereas age-eligible individuals in the largest localities (those with 100,000 or more inhabitants) are our control group $\left(T_{i}=0\right)$. We also include individuals 55 to 69 years old in both types of localities as an additional control group in our analysis because they do not qualify for the program, regardless of the locality they live in. ${ }^{18}$ As such, the coefficient $\gamma_{1}$ captures the effect of the program -that is, the impact of being age-eligible in a treated locality after the program started- on the probability of receiving remittances. Similarly, $\delta_{1}$ captures the effect of the program on the overall magnitude that remittance-receiving individuals get. By using our triple-difference strategy, these treatment effects are already purged from any confounders affecting the remittances received by all individuals age 55 and older in our sample over time, any trends affecting remittances received by individuals age 70 and older over time, and any locality-level changes affecting remittances received by all individuals 55 and older in treated areas that are unrelated to the program.

By using older individuals in localities with 100,000 or more inhabitants as controls, we ensure that the control group did not participate in the program as of 2008. However, age-eligible individuals in the largest localities in Mexico might be different from those living in the smallest ones. To address this concern, we explicitly account for differences in the socio-demographic characteristics of individuals by including in $X_{i}$ their age, educational attainment (primary or less, secondary, college and beyond), a household head indicator and information on the share of household members that are young children (6 years of age or younger) or elderly (65 years of age or older). Additionally, as a robustness check, in section 6.2 we experiment with alternative definitions of the treatment and control groups. 
In all our estimations, we also control for municipality fixed effects $\left(\delta_{m}\right)$ to account for local differences potentially impacting remittance inflows, such as migration rates. Standard errors are clustered at the municipality level to account for the serial correlation problem typically present in difference-in-differences applications (Bertrand, Duflo and Mullainathan, 2004). ${ }^{19}$ Finally, we perform the analysis for all individuals, as well as separately for men and women.

\section{Some Descriptive Statistics}

Table 1 displays some descriptive statistics for the individuals age 55 and older and their households in 2006, in each of the four groups of localities described earlier. The first two columns show that the share of individuals reporting receiving any remittances in relatively small localities, i.e. those with less than 15,000 inhabitants, fluctuates around 24 percent, but drops to 21 and 17 percent as the size of the locality gets larger. In general, approximately 16 to 19 percent of individuals report receiving domestic remittances, but only 2 to 8 percent report receiving international money transfers. The share of elderly individuals receiving international remittances is larger in smaller localities than in larger ones, and such transfers also represent a larger share of the private support received.

Individuals in our sample also differ in other regards across locality groups. For instance, the share of individuals 70 years of age is larger in smaller rural localities, while their educational attainment is lower. About 93 percent of individuals age 55 and older in localities with less than 2,500 inhabitants have elementary education or less, relative to 65 percent in localities with more than 100,000 inhabitants. Finally, individuals in the smallest localities also have lower total individual income (1,688 pesos or 135 USD per month) compared to individuals in larger localities. ${ }^{20}$

To provide descriptive evidence on the effect of the 70 y Más program on the amount of public and private transfers received by the targeted group, Table 2 displays the means of 
these transfers for individuals in our treatment and control groups between 2006 and 2008, before and after the program, respectively. ${ }^{21}$ In Panel A, the DT column shows that the mean government transfers received by individuals age 70 and older in localities with less than 2,500 inhabitants, the ones targeted by the program, increased by 201 pesos per month between 2006 and 2008. Likewise, the mean of the total remittances they receive decreased by 97 pesos per month -the reduction being particularly larger in the case of domestic ones. These differences in means are statistically significant at conventional levels. In contrast, the DC column shows that the change in either government or private transfers experienced by age-qualifying individuals in control localities was much smaller than in the DT column and not statistically different from zero. As a result, the DD column reveals that age-qualifying individuals in treated localities did experience a statistically significant increase of 143 pesos/month in government transfers after the program started. The same column shows that they also experienced a decline in the remittances they receive from both domestic and international donors, but such reductions are not statistically significant.

We perform equivalent calculations for younger non-qualifying individuals in Panel B to compare the difference-in-difference estimates from the two age groups. As can be seen in the DT and DC columns in Panel B, the government transfers received by individuals age 55 to 69 in treated and control localities also increased slightly between 2006 and 2008, while their remittances decreased. The latter could be due to factors, other than the 70 y Más program, affecting remittance inflows received by this younger group in both types of localities. However, the DD column demonstrates that those changes were smaller than those experienced by their older counterparts in Panel A. Consequently, the triple-difference estimates in the last column of Panel A confirm that the 70 y Más program effectively increased the government transfers paid to the targeted group by 139 pesos/month. In that same column, the triple-difference estimate for the total amount of remittances received 
implies a crowding out of 42 percent (-58/139). While negative, the estimate is not statistically significant, and neither are the reductions in domestic and international remittances. Nevertheless, the evidence in this table is purely descriptive. In what follows, we enhance the analysis by controlling for relevant covariates and distinguishing between the crowding out at the extensive and intensive margins.

\section{Does the 70 y Más Program Crowd Out Private Transfers?}

\section{Main Findings}

Table 3 shows the results from estimating equations (1) and (2) for individuals age 55 and older using OLS. Columns 1, 3 and 5 display, correspondingly, the estimates for the probability of receiving any remittances -domestic or international. Columns 2, 4 and 6 show the results for the log amounts reported by remittance-receiving individuals. In all columns, the first row presents the estimated treatment effect, which is the coefficient on the interaction of being age 70 and older in a treated locality in 2008. As mentioned before, we attribute the effect of this triple interaction to the program because it captures the change in the outcome of interest for age-eligible individuals in treated localities between 2006 and 2008, after differencing out the corresponding change for same-age individuals in control localities, and those for individuals age 55 to 69 in treated versus control localities.

The estimated treatment effect in column 1, which is significant at the 5 percent level, shows that individuals age 70 and older residing in a treated locality in 2008 were 6.6 percentage points less likely to receive any remittances, compared to same-age individuals in control localities, and younger individuals in all localities. As reported in Panel A of Table A in the appendix, the fraction of age-eligible individuals in the treatment group who reported receiving any remittances in 2006, before the program started, was 32 percent. Therefore, the program lowered this probability by roughly 21 percent, after accounting for any changes affecting the remittance receipt of all individuals in our sample over time, specific trends 
affecting those who are age 70 and older, and locality-level confounding changes. Column 2, in turn, shows that the program had a negative, but small and not statistically significant, impact on the total amount reported by remittance-receiving individuals. Given that we observe crowding out at the extensive margin only, we can get the corresponding estimate in pesos by multiplying the treatment effect in column $1(-0.066)$ by the mean amount reported by treated individuals receiving positive remittances before the program (769 pesos, as shown in Panel B, Table A). This yields a reduction of 51 pesos/month -approximately 37 percent of the increase in mean government transfers received by age-qualifying individuals in Table 2.

To shed some more light on these results, columns 3 through 6 distinguish private transfers according to their origin. The implementation of the 70 y Más program appears to have crowded out domestic private transfers, but not international ones. Specifically, the triple-difference estimate in column 3 shows that the program lowered the probability of receiving domestic remittances by 7.8 percentage points -a 31 percent reduction with respect to the 0.25 probability of this group before the program (Panel A, Table A). On the contrary, the program had no statistically significant impact on the likelihood of receiving international remittances. Likewise, it did not significantly alter the magnitude of domestic or international inflows of remittance-receiving individuals.

In all columns, the coefficients of the dummies for 2008, age 70 and older and treated locality, together with those of their double interactions, are mostly statistically insignificant, implying that differences in the outcome variable between age groups and types of localities, as well as age and locality specific trends, are mostly unimportant after controlling for the relevant socio-demographic variables. The few exceptions to this are: (a) the negative and significant coefficient of the 2008 dummy in column 2, showing that remittance-receiving individuals in our sample, regardless of their age and locality of residence, experienced a 20 
percent decrease in the total amounts received in 2008 relative to 2006; and (b) the negative and significant effects of being age 70 and older in a treated locality in columns 2 and 4 . That last result suggests that remittance-receivers who were age-eligible and resided in treated localities received a 35 and 28 percent lower amount of domestic and total transfers in 2006, compared to same-age seniors in control localities, and younger ones in the same localities. Same-age seniors in urban areas face higher costs of living, and younger seniors in rural areas are more likely to reside with children and prime-age adults. Thus, conditional on receiving positive remittances, one would expect these two ineligible groups to receive larger amounts compared to individuals age 70 and older in rural areas even in the absence of the program.

Other explanatory variables in Table 2 have the expected signs. For instance, men were less likely to receive remittances than women and, if they reported receiving any, their magnitude was smaller. Similarly, more educated individuals were less likely to receive remittances than their less educated counterparts. Yet, when they reported receiving a positive sum, its magnitude was generally larger. This might occur if their education is positively correlated with that of their donors and more educated donors are capable of remitting larger sums when they actually do so. Not surprisingly, household heads were more likely to receive remittances, and they also get larger amounts. Finally, individuals residing in households with a larger share of elderly members were also more likely to receive private transfers.

Table 4 looks at the crowding out effects of 70 y Más by gender. According to column 1, the program lowered the likelihood of receiving any remittances by 3.6 percentage points among men (Panel A) and by 10.4 percentage points among women (Panel B), but only the latter is statistically significant. The effect for women is also proportionally larger, as it represents a 30 percent reduction in the probability of receiving such transfers before the 
program, compared to a 13 percent reduction among men. ${ }^{22}$ In pesos, the program lowered total remittances by 41 pesos among men and by 93 pesos among women. These figures amount to approximately 29 percent and 70 percent, respectively, of the 139 pesos mean increase in government transfers reported in Table $2 .{ }^{23}$ Thus, the overall crowding out is, not only larger for elderly women than for their male counterparts, but also statistically different from zero. This finding is expected if remittances sent to women are transferred precisely to palliate their lower receipt of contributory pensions relative to men.

Columns 3 and 5 in Table 4 show that, as before, the program significantly reduced the receipt of domestic transfers for both men and women, but had no significant impact on the receipt of international remittances. ${ }^{24}$ In addition, the program did not significantly affect any of the magnitudes reported by remittance-receiving men and women (columns 2, 4 and $6)$.

In summary, our results suggest that the 70 y Más program partially crowded out the private support received by the elderly by reducing their probability of receiving domestic remittances. Thus, for domestic remittances, crowding out is concentrated at the extensive margin, which is reasonable given that the increase in government transfers experienced by treated individuals in Table 2 (139 pesos) is close to the average domestic remittances they received in 2006 (140 pesos). This means that, for some beneficiaries, the transfer from $70 y$ Más could actually fully replace the amount they used to get from their families. In contrast, the program had no effect on international remittances, which could be due to differences in the motives driving domestic and international remittances, or to donors in Mexico being more informed about the program than those abroad. Anecdotal evidence supports the latter given that the start of the program in 2007 was widely publicized within Mexico, both at the local and national level. ${ }^{25}$ In addition, the program was constantly advertised as one of the main elements of the federal government's development strategy, called Vivir Mejor. ${ }^{26}$ Thus, 
domestic donors were able to observe the increase in public support enjoyed by their elderly relatives and, as a result, reduce their own private support.

Our estimated effects are comparable to those in Jensen (2004) for rural households in South Africa, and smaller than the almost complete crowding out estimated by Juarez (2009) for DF residents age 70 and older. The composition of the private transfers received by the Mexican elderly in rural and urban areas might partly explain the differences between our results and those in Juarez (2009). As shown in Panel A of Table A in the appendix, the mean remittance amount received by individuals age 70 and older in localities with less than 2,500 inhabitants (254 pesos per month) is not extremely different from that of similar individuals in localities with 100,000 or more inhabitants (274 pesos per month). However, for our treatment group of rural individuals, domestic remittances represent 60 percent of all private transfers, whereas for our control group of urban individuals these transfers represent 87 percent. $^{27}$ If public transfers primarily reduce the likelihood of receiving domestic remittances, as we find, then those receiving a higher proportion of this type of transfers would experience a larger crowding out and, as a result, would gain less from government redistributive efforts.

\section{Robustness Checks}

We perform a number of robustness checks to support the validity of our results, which we report in Table 5. First, we double check a key assumption in our triple-differences approach -namely, the non-existence of pre-program trends driving our results. To that end, we use data from the ENIGH 2004 and 2006 rounds, both before the implementation of the 70 y Más program, to perform a placebo test. Second, we check whether using alternative definitions of the control and treatment groups, based on our locality-size group variables, affects our results. This robustness check allows us to address any concerns regarding the comparability of small (treated) and larger (control) localities by ultimately comparing 
individuals in all types of locality sizes. Third, since some Mexican states implemented their own non-contributory pension schemes for elderly individuals starting in 2001 (Aguila et al. 2011), we exclude from our estimations those states that implemented their own cash transfers programs for the elderly at the same time as 70 y Más. Finally, we check whether our results obtained for elderly individuals hold at the household level.

The results from our placebo test are displayed in Panel A of Table 5. The first row shows that being age-eligible in a locality with less than 2,500 inhabitants in 2006 (the "after" round in our test) did not significantly affect the likelihood of receiving remittances or the amounts received. Therefore, we find no evidence of pre-program trends potentially driving the crowding out effect of 70 y Más in Table 3.

In Panels B and C of Table 5, we experiment with alternative definitions of the control and treatment groups. As mentioned in section 3, at the end of 2007, the program was extended to localities with up to 20,000 inhabitants. Hence, individuals in localities with 2,500-14,999 inhabitants were incorporated to the program during 2008, together with some individuals in localities with 15,000-99,999 inhabitants, though not all of them. In both panels, we use individuals in localities with less than 15,000 inhabitants as our treated group. In Panel B, we use individuals in localities with 100,000 or more inhabitants as our control group, as before, whereas in Panel C we use individuals in all localities with 15,000 and more inhabitants as controls. As can be seen, these alternative specifications yield very similar results. In both cases, the 70 y Más program reduced the likelihood of receiving any remittances by 5 to 6 percentage points, mostly by reducing that of receiving domestic ones by 6 to 7 percentage points. And, once more, the program did not significantly impact the probability of receiving international remittances, or the amounts of individuals still receiving positive transfers from any source. 
In Panel D of Table 5, we address the potential biases introduced by the overlap of state-level public assistance programs for the rural elderly by excluding the seven states that implemented such programs between 2006 and 2008 from our main sample. ${ }^{28}$ As shown in the first row of that panel, the overall effects of the program on remittance receipt are similar to those presented in Table 3, except somewhat stronger. This is expected given that some state-level programs cover individuals who belong to our control group because they are not eligible for 70 y Más. ${ }^{29}$ Specifically, age-eligible individuals in treated localities were 7.6 percentage points less likely to receive any remittances after the 70 y Más program (column 1, Table 7), because they were 9.7 percentage points less likely to receive domestic ones. As before, the probability of receiving international remittances, and the amounts received, remained unaffected by the program (columns 3 and 5, Table 7), which is once again consistent with our main estimates in Table 3.

As a final robustness check, we repeat our analysis using the household, as opposed to the individual, as our unit of observation. In these regressions, our key independent variable is the triple interaction of dummy variables for having at least one household member who is age 70 and older, for being in a locality with less than 2,500 inhabitants and for 2008. The results, displayed in Panel E of Table 5, are broadly consistent with our individual-level findings. The 70 y Más program significantly reduced the probability of receiving domestic remittances by 13 percentage points and, as a result, the overall likelihood of receiving any private transfers by the same magnitude. Once again, no other significant effects are found.

To conclude, it is worth addressing a concern not discussed earlier -namely the possibility that the program might have induced the elderly to migrate to smaller, treated localities in order to qualify for benefits. In results available from the authors, we find no evidence of a statistically significant relationship between the likelihood of living in a treated locality and being age 70 and older, after the program started. Still, a related and more 
general concern is that other changes in living arrangements might be responsible for the observed decline in the likelihood of private transfers. For instance, if the program encourages the elderly to move-in with former donors or vice versa, we might observe a decrease in the remittances received individually by seniors; not because of crowding out, but just because they are all now part of the same household. However, in household-level regressions available from the authors, we find that having any age-eligible individual in a treated locality in 2008 has a small and negative (as opposed to positive) effect on household size. The impact is, nonetheless, only statistically different from zero at the 10 percent level. Thus, our crowding out results cannot be explained by a confounding change in the locality the elderly reside in or in their living arrangements.

\section{How is the 70 y Más Program Impacting Individual Non-labor Incomes?}

Our partial crowding out estimates suggest that the actual increase in non-labor income experienced by program beneficiaries might have been smaller than what the government originally intended. To assess whether that is indeed the case, Table 6 displays the results from estimating individual-level regressions similar to equations (1) and (2) using government transfers received and non-labor income as our dependent variables. Government transfers include any public cash transfer programs, except for Progresa and Procampo. ${ }^{30}$ Non-labor income includes government and private transfers, pensions, rent, capital, and other non-labor income. We look at non-labor income, as opposed to total income, because labor income is more likely to change in response of the program through a reduction in the labor supply of beneficiaries.

The figures in Table 6 confirm that the program significantly increased the government transfers of age-qualifying individuals in treated localities by raising the probability of receiving them by 51 percentage points. However, as found for private transfers, the program did not significantly change the magnitude of the amounts reported by 
individuals who were already receiving government transfers. The mean amount of government transfers received by those who report positive amounts in 2008 is 352 pesos per month. Therefore, according to the estimate in column 1, the program increased government transfers by 180 pesos -a figure higher than the average of 139 pesos per month in Table 2.

Did the non-labor income of beneficiaries increase by a similar amount, or by less due to the estimated impact of the 70 y Más program on private transfers? According to the figures in column 3 of Table 6, the program raised the likelihood of reporting any non-labor income by 18 percentage points, but not the amount earned. The average non-labor income of age-eligible individuals who reported a positive one in 2008 was 857 pesos per month. Hence, our estimate suggests that the program raised the non-labor income of beneficiaries by 153 pesos per month -an amount 15 percent smaller than the 180 peso/month increase in government transfers reported above. For individuals whose non-labor income is below the mean, the income increase caused by the program is about 52 percent less than the increase in government transfers. ${ }^{31}$ These calculations imply that the crowding out of private transfers caused by the 70 y Más program dampened the beneficiaries’ expected increase in non-labor income by a significant amount, particularly for those with lower incomes.

\section{Summary and Conclusions}

In 2007, the Mexican government implemented 70 y Más, a public income support program for individuals age 70 and older in rural localities, with the explicit goal of raising their incomes. In this paper, we find that the program partially crowded out the monetary support that the elderly get from their families, thus undermining its goal. Specifically, we estimate an overall crowding out of private transfers of 37 percent. Elderly women experience an even larger crowding out compared to men. In all cases, the overall crowding out is mostly due to a significant reduction in the probability of receiving domestic remittances among individuals targeted by the program. In contrast, the public transfers did 
not seem to have significantly impacted the flow of international remittances at either the extensive or intensive margins.

The differential response of remittances according to their origin suggests that domestic and international donors might have distinct motivations to send such funds. After all, it is reasonable to expect that public transfers might crowd out private transfers that are motivated by either altruism or exchange, but not necessarily those given for self-insurance or investment purposes. Alternatively, given that the program was widely publicized in Mexico, domestic donors might have been more informed about the public transfer than international ones and, therefore, more likely to respond to it. In any case, such differential responses imply that some of the program resources are unintentionally reaching younger donors in Mexico, if not their counterparts residing abroad. Furthermore, the crowding out in urban areas, now covered by the program, could prove significantly larger given that the elderly in those areas receive a higher share of remittances from domestic donors - the most responsive to the program.

Non-contributory pension schemes like 70 y Más have become increasingly popular in Mexico and other developing countries as governments strive to provide for the elderly, particularly when they do not qualify for a contributory pension. However, our estimates imply that, as a result of the crowding out of private transfers, the non-labor income of targeted individuals increased by 15 to 52 percent less than their government transfers. In sum, the effectiveness of such schemes in raising the elderly's incomes might have been somewhat hampered, thus warranting more thought on how to best attain that goal and insure that population against poverty. 


\section{References}

Aguila, Emma, Claudia Diaz, Mary Manqing Fu, Arie Kapteyn and Ashley Pierson. 2011. Living Longer in Mexico: Income Security and Health. Santa Monica, CA: RAND Corporation. Available at: http://www.rand.org/pubs/monographs/MG1179.

Amuedo-Dorantes, Catalina and Pozo, Susan. 2006. Remittances and Insurance: Evidence from Mexican Migrants. Journal of Population Economics 19(2): 227-254.

Andreoni, James. 1989. Giving with Impure Altruism: Applications to Charity and Ricardian Equivalence. Journal of Political Economy 97 (6): 1447-1458.

Andreoni, James. 1990. Impure Altruism and Donations to Public Goods: A Theory of Warm-Glow Giving. Economic Journal 100 (401): 464-477.

Auditoría Superior de la Federación. Informe del Resultado de la Fiscalización Superior de la Cuenta Pública 2010. Auditoría Financiera y de Cumplimiento. Programa 70 y Más. Available at: http://www.asf.gob.mx/Trans/Informes/IR2010i/Grupos/Desarrollo_Social/2010_0882.pdf

Becker, Gary. 1974. A Theory of Social Interactions. Journal of Political Economy 82(6): 1063-1093.

Bernheim, B. Douglas, Andrei Shleifer, and Lawrence H. Summers. 1985. The Strategic Bequest Motive. Journal of Political Economy 93(6): 1045-76. 
Bertrand, Marianne, Esther Duflo, and Sendhil Mullainathan. 2004. How Much Should We Trust Differences-in-Differences Estimates?. Quarterly Journal of Economics 119(1): 249275.

Brunner, Eric J. 1998. Free riders or easy riders? An Examination of the Voluntary Provision of Public Radio. Public Choice 97: 587-604.

Consejo Nacional de Evaluación de la Política de Desarrollo Social. Informe de la Evaluación Específica de Desempeño 2008. Available at www.coneval.gob.mx.

Cox, Donald. 1987. Motives for Private Income Transfers. Journal of Political Economy 95(3): 508-546.

Diario Oficial de la Federación. 2007. Acuerdo por el que se emiten y publican las Reglas de Operación del Programa de Atención a los Adultos Mayores de 70 años y más en zonas rurales para el ejercicio fiscal 2007. Published on February 28th, 2007. Available at: http://www.dof.gob.mx/

Durand, Jorge, William Kandel, Emilio A. Parrado and Douglas S. Massey.1996. International Migration and Development in Mexican Communities. Demography 33(2): 249-64.

Galiani, Sebastian and Paul Gertler. 2009. Primer Seguimiento a la Evaluación de Impacto del Programa de Atención a Adultos Mayores de 70 Años y Más en Zonas Rurales. Informe Final Sobre los Cambios del Programa 70 y Más. Instituto Nacional de Salud Pública y 
Secretaria de Desarrollo Social. Available at: http://www.20062012.sedesol.gob.mx/en/SEDESOL/70_y_mas

Gubert, Flore. 2002. Do Migrants Insure Those who Stay Behind? Evidence from the Kayes Area (Western Mali). Oxford Development Studies 30(3): 267-287.

Guthrie, Amy. 2012. Mexico Expands Elderly Benefit Programs to Urban Areas. The Wall Street Journal. January 17. Available at: http://online.wsj.com/article/BT-CO-20120117713958.html

Jensen, Robert T. 2004. Do Private Transfers 'Displace' the Benefits of Public Transfers? Evidence from South Africa. Journal of Public Economics 88(1-2): 89-112.

Juarez, Laura. 2009. Crowding out of private support to the elderly: Evidence from a demogrant in Mexico. Journal of Public Economics 93(3-4):454-463.

Levy, Santiago and Norbert Schady. 2013. Latin America’s Social Policy Challenge: Education, Social Insurance, Redistribution. Journal of Economic Perspectives 27(2): 193218.

Lucas, Robert E.B. and Oded Stark. 1985. Motivations to Remit: Evidence from Botswana, Journal of Political Economy 93(5): 901-918. 
Table 1: Descriptive statistics before the program (2006)

\begin{tabular}{|c|c|c|c|c|c|c|c|c|}
\hline \multirow{2}{*}{$\begin{array}{l}\text { Locality Size } \\
\text { Descriptive Statistic }\end{array}$} & \multicolumn{2}{|c|}{$\begin{array}{l}\text { In localities } \\
<2,500\end{array}$} & \multicolumn{2}{|c|}{$\begin{array}{l}\text { In localitites } \\
2,500-14,999\end{array}$} & \multicolumn{2}{|c|}{$\begin{array}{c}\text { In localitites } \\
15,000-99,999\end{array}$} & \multicolumn{2}{|c|}{$\begin{array}{c}\text { In localities } \\
>100,000\end{array}$} \\
\hline & Mean & SD & Mean & SD & Mean & SD & Mean & SD \\
\hline Received any remittances & 0.24 & 0.43 & 0.25 & 0.43 & 0.21 & 0.41 & 0.17 & 0.38 \\
\hline Received any domestic remittances & 0.18 & 0.38 & 0.19 & 0.40 & 0.17 & 0.38 & 0.16 & 0.37 \\
\hline Received any international remittances & 0.08 & 0.28 & 0.06 & 0.24 & 0.05 & 0.21 & 0.02 & 0.15 \\
\hline Total remittances received & 200.87 & 890.36 & 169.16 & 553.48 & 177.66 & 573.67 & 214.15 & 1117.35 \\
\hline Domestic remittances received & 111.99 & 734.35 & 92.07 & 307.83 & 118.32 & 396.96 & 179.61 & 1054.32 \\
\hline International remittances received & 88.88 & 510.07 & 77.10 & 468.29 & 59.34 & 420.19 & 34.54 & 360.11 \\
\hline Age 70 and older & 0.36 & 0.48 & 0.39 & 0.49 & 0.32 & 0.47 & 0.32 & 0.47 \\
\hline Male & 0.49 & 0.50 & 0.47 & 0.50 & 0.47 & 0.50 & 0.45 & 0.50 \\
\hline Age & 67.22 & 9.45 & 67.53 & 9.45 & 66.47 & 9.18 & 66.05 & 9.22 \\
\hline No instruction or elementary education & 0.93 & 0.25 & 0.90 & 0.30 & 0.78 & 0.41 & 0.65 & 0.48 \\
\hline Secondary or high school education & 0.04 & 0.20 & 0.07 & 0.26 & 0.12 & 0.32 & 0.17 & 0.37 \\
\hline College education and beyond & 0.02 & 0.15 & 0.03 & 0.17 & 0.10 & 0.30 & 0.18 & 0.38 \\
\hline Household head & 0.60 & 0.49 & 0.63 & 0.48 & 0.62 & 0.48 & 0.61 & 0.49 \\
\hline Individual total income & 1688 & 5052 & 2006 & 7318 & 3232 & 5484 & 4349 & 7453 \\
\hline Number of observations & \multicolumn{2}{|c|}{3148} & \multicolumn{2}{|c|}{950} & \multicolumn{2}{|c|}{2049} & \multicolumn{2}{|c|}{4117} \\
\hline
\end{tabular}

Sample: Individuals age 55+ from ENIGH 2006. Remittances, income and expenditures are in real pesos per month. 
Table 2: Average Public and Private Transfers per Month

\begin{tabular}{|c|c|c|c|c|c|c|c|c|}
\hline & \multicolumn{3}{|c|}{ Localities $<2,500$} & \multicolumn{3}{|c|}{ Localities $>100,000$} & \multirow{2}{*}{$\begin{array}{c}\text { DD } \\
\text { (DT-DC) }\end{array}$} & \multirow{2}{*}{$\begin{array}{c}\text { DDD } \\
\text { (DDA-DDB) }\end{array}$} \\
\hline & 2006 & 2008 & DT & 2006 & 2008 & DC & & \\
\hline \multicolumn{9}{|c|}{ Panel A: Individuals age 70+ } \\
\hline Government transfers & $\begin{array}{c}30.75 \\
(5.951)\end{array}$ & $\begin{array}{c}231.9 \\
(5.058)\end{array}$ & $\begin{array}{c}201.2^{* * *} \\
(7.783)\end{array}$ & $\begin{array}{c}75.04 \\
(5.183)\end{array}$ & $\begin{array}{c}133.5 \\
(37.07)\end{array}$ & $\begin{array}{c}58.54 \\
(51.44)\end{array}$ & $\begin{array}{c}142.7^{* *} \\
(60.92)\end{array}$ & $\begin{array}{l}138.7 * * * \\
(44.01)\end{array}$ \\
\hline Total remittances & $\begin{array}{c}295.2 \\
(39.86)\end{array}$ & $\begin{array}{c}198.1 \\
(18.54)\end{array}$ & $\begin{array}{c}-97.08^{* *} \\
(40.75)\end{array}$ & $\begin{array}{c}387.9 \\
(49.63)\end{array}$ & $\begin{array}{c}358.0 \\
(25.67)\end{array}$ & $\begin{array}{l}-29.95 \\
(50.49)\end{array}$ & $\begin{array}{l}-67.13 \\
(68.66)\end{array}$ & $\begin{array}{l}-58.32 \\
(69.05)\end{array}$ \\
\hline Domestic remittances & $\begin{array}{c}140.4 \\
(26.97)\end{array}$ & $\begin{array}{c}77.31 \\
(10.33)\end{array}$ & $\begin{array}{c}-63.15^{* *} \\
(26.33)\end{array}$ & $\begin{array}{c}264.1 \\
(36.69)\end{array}$ & $\begin{array}{c}224.0 \\
(17.33)\end{array}$ & $\begin{array}{l}-40.10 \\
(35.75)\end{array}$ & $\begin{array}{l}-23.05 \\
(47.59)\end{array}$ & $\begin{array}{l}-26.75 \\
(45.30)\end{array}$ \\
\hline International remittances & $\begin{array}{c}83.53 \\
(14.11)\end{array}$ & $\begin{array}{c}62.23 \\
(8.225)\end{array}$ & $\begin{array}{l}-21.31 \\
(15.51)\end{array}$ & $\begin{array}{c}30.21 \\
(8.180)\end{array}$ & $\begin{array}{c}28.08 \\
(5.429)\end{array}$ & $\begin{array}{l}-2.133 \\
(9.559)\end{array}$ & $\begin{array}{l}-19.17 \\
(17.26)\end{array}$ & $\begin{array}{l}-8.469 \\
(23.30)\end{array}$ \\
\hline $\mathrm{N}$ & 1130 & 1483 & 2613 & 1307 & 2503 & 3810 & 6423 & 19288 \\
\hline \multicolumn{9}{|c|}{ Panel B: Individuals age 55-69 } \\
\hline Government transfers & $\begin{array}{c}7.259 \\
(1.648)\end{array}$ & $\begin{array}{c}16.22 \\
(2.932)\end{array}$ & $\begin{array}{c}8.966^{* *} \\
(3.686)\end{array}$ & $\begin{array}{c}1.550 \\
(0.719)\end{array}$ & $\begin{array}{c}6.508 \\
(2.706)\end{array}$ & $\begin{array}{c}4.958 \\
(3.760)\end{array}$ & $\begin{array}{c}4.009 \\
(5.593)\end{array}$ & \\
\hline Total remittances & $\begin{array}{c}247.7 \\
(23.79)\end{array}$ & $\begin{array}{c}162.4 \\
(14.05)\end{array}$ & $\begin{array}{c}-85.20 * * * \\
(26.20)\end{array}$ & $\begin{array}{c}233.0 \\
(24.40)\end{array}$ & $\begin{array}{l}156.68 \\
(9.731)\end{array}$ & $\begin{array}{c}-76.39 * * * \\
(22.22)\end{array}$ & $\begin{array}{l}-8.809 \\
(34.92)\end{array}$ & \\
\hline Domestic remittances & $\begin{array}{c}96.04 \\
(13.73)\end{array}$ & $\begin{array}{c}52.16 \\
(4.470)\end{array}$ & $\begin{array}{c}-43.87 * * * \\
(12.93)\end{array}$ & $\begin{array}{c}140.2 \\
(16.93)\end{array}$ & $\begin{array}{c}92.71 \\
(6.111)\end{array}$ & $\begin{array}{c}-47.58^{* * *} \\
(14.90)\end{array}$ & $\begin{array}{c}3.704 \\
(21.53)\end{array}$ & \\
\hline International remittances & $\begin{array}{c}91.87 \\
(11.77)\end{array}$ & $\begin{array}{c}62.24 \\
(8.896)\end{array}$ & $\begin{array}{c}-29.62 * * \\
(14.48)\end{array}$ & $\begin{array}{c}36.54 \\
(7.290)\end{array}$ & $\begin{array}{c}17.62 \\
(3.061)\end{array}$ & $\begin{array}{c}-18.92 * * * \\
(6.768)\end{array}$ & $\begin{array}{l}-10.70 \\
(14.16)\end{array}$ & \\
\hline $\mathrm{N}$ & 2018 & 2714 & 4732 & 2810 & 5323 & 8133 & 12865 & \\
\hline
\end{tabular}

Notes: Means are estimated using OLS and all observations, including those with zero public or private transfers. Robust standard errors in parentheses. $* * * p<0.01, * * p<0.05$, ${ }^{*}<0.1$ 
Table 3: OLS results for remittances received by individuals age 55+

\begin{tabular}{|c|c|c|c|c|c|c|}
\hline & (1) & (2) & (3) & (4) & (5) & (6) \\
\hline & $\begin{array}{c}\text { Any } \\
\text { Remittances } \\
\end{array}$ & $\begin{array}{c}\text { Log (Total } \\
\text { Remittances) }\end{array}$ & $\begin{array}{c}\text { Any Domestic } \\
\text { Remittances }\end{array}$ & $\begin{array}{c}\text { Log (Domestic } \\
\text { Remittances) }\end{array}$ & $\begin{array}{c}\text { Any International } \\
\text { Remittances }\end{array}$ & $\begin{array}{c}\text { Log (International } \\
\text { Remittances) }\end{array}$ \\
\hline \multirow[t]{2}{*}{ Treatment Effect } & $-0.066 * *$ & -0.041 & $-0.078 * * *$ & 0.010 & 0.003 & 0.141 \\
\hline & $(0.028)$ & $(0.192)$ & $(0.025)$ & $(0.240)$ & $(0.016)$ & $(0.559)$ \\
\hline \multirow[t]{2}{*}{ Year 2008} & -0.013 & $-0.197 * *$ & -0.016 & -0.154 & -0.001 & -0.084 \\
\hline & $(0.012)$ & $(0.090)$ & $(0.011)$ & $(0.094)$ & $(0.003)$ & $(0.333)$ \\
\hline \multirow[t]{2}{*}{ Age $70+$} & 0.009 & 0.153 & 0.004 & 0.171 & -0.002 & 0.120 \\
\hline & $(0.016)$ & $(0.130)$ & $(0.015)$ & $(0.149)$ & $(0.007)$ & $(0.306)$ \\
\hline \multirow[t]{2}{*}{ Treated Locality } & 0.013 & -0.060 & -0.002 & -0.006 & 0.013 & 0.282 \\
\hline & $(0.027)$ & $(0.181)$ & $(0.025)$ & $(0.192)$ & $(0.014)$ & $(0.580)$ \\
\hline \multirow[t]{2}{*}{ (Age 70+)*(Treated Locality) } & -0.026 & $-0.276^{*}$ & -0.005 & $-0.350 * *$ & -0.016 & -0.158 \\
\hline & $(0.021)$ & $(0.145)$ & $(0.019)$ & $(0.165)$ & $(0.012)$ & $(0.345)$ \\
\hline \multirow[t]{2}{*}{ (Age 70+)*(Year 2008) } & 0.025 & 0.092 & 0.023 & 0.072 & 0.003 & -0.162 \\
\hline & $(0.016)$ & $(0.122)$ & $(0.015)$ & $(0.137)$ & $(0.006)$ & $(0.484)$ \\
\hline \multirow[t]{2}{*}{ (Treated Locality)*(Year 2008) } & -0.005 & -0.097 & 0.001 & -0.147 & -0.000 & -0.325 \\
\hline & $(0.021)$ & $(0.165)$ & $(0.018)$ & $(0.190)$ & $(0.011)$ & $(0.425)$ \\
\hline \multirow[t]{2}{*}{ Male } & $-0.171 * * *$ & $-0.129 * *$ & $-0.149 * * *$ & $-0.132 * *$ & $-0.034 * * *$ & -0.054 \\
\hline & $(0.007)$ & $(0.056)$ & $(0.007)$ & $(0.060)$ & $(0.004)$ & $(0.139)$ \\
\hline \multirow[t]{2}{*}{ Age } & $0.001^{* *}$ & $-0.008^{*}$ & $0.002^{* * *}$ & -0.007 & 0.000 & -0.010 \\
\hline & $(0.001)$ & $(0.004)$ & $(0.001)$ & $(0.005)$ & $(0.000)$ & $(0.011)$ \\
\hline \multirow[t]{2}{*}{ Secondary Education } & $-0.042 * * *$ & $0.641^{* * *}$ & $-0.035 * * *$ & $0.677 * * *$ & $-0.010 * *$ & $0.528 *$ \\
\hline & $(0.008)$ & $(0.081)$ & $(0.008)$ & $(0.087)$ & $(0.004)$ & $(0.307)$ \\
\hline \multirow[t]{2}{*}{ Tertiary Education } & $-0.068 * * *$ & $0.696 * * *$ & $-0.057 * * *$ & $0.759 * * *$ & $-0.016^{* * *}$ & 0.542 \\
\hline & $(0.009)$ & $(0.088)$ & $(0.009)$ & $(0.082)$ & $(0.004)$ & $(0.581)$ \\
\hline \multirow[t]{2}{*}{ HH Head } & $0.129 * * *$ & $0.348 * * *$ & $0.111 * * *$ & $0.261 * * *$ & $0.028 * * *$ & $0.411^{* * *}$ \\
\hline & $(0.007)$ & $(0.051)$ & $(0.007)$ & $(0.056)$ & $(0.004)$ & $(0.143)$ \\
\hline \multirow[t]{2}{*}{ Share of Children in the $\mathrm{HH}$} & $-0.060^{*}$ & -0.249 & $-0.088 * * *$ & -0.479 & 0.024 & -0.444 \\
\hline & $(0.034)$ & $(0.319)$ & $(0.032)$ & $(0.382)$ & $(0.019)$ & $(0.453)$ \\
\hline \multirow[t]{2}{*}{ Share of Elderly HH Members } & $0.133^{* * *}$ & 0.017 & $0.124^{* * *}$ & 0.036 & $0.015^{* * *}$ & 0.090 \\
\hline & $(0.010)$ & $(0.077)$ & $(0.010)$ & $(0.082)$ & $(0.005)$ & $(0.211)$ \\
\hline Municipality FE & YES & YES & YES & YES & YES & YES \\
\hline Observations & 19,298 & 3,615 & 19,298 & 2,917 & 19,298 & 855 \\
\hline Adjusted $\mathrm{R}^{2}$ & 0.113 & 0.182 & 0.0953 & 0.202 & 0.121 & 0.160 \\
\hline
\end{tabular}

Notes: All regressions include a constant term. Robust standard errors (in parentheses) are clustered at the municipal level. ${ }^{* * *} \mathrm{p}<0.01, * * \mathrm{p}<0.05,{ }^{*} \mathrm{p}<0.1$ 
Table 4: OLS results for remittances received by men and women age 55+

\begin{tabular}{|c|c|c|c|c|c|c|}
\hline & (1) & (2) & (3) & (4) & (5) & (6) \\
\hline & $\begin{array}{c}\text { Any } \\
\text { Remittances }\end{array}$ & $\begin{array}{c}\text { Log (Total } \\
\text { Remittances) }\end{array}$ & $\begin{array}{c}\text { Any Domestic } \\
\text { Remittances }\end{array}$ & $\begin{array}{c}\text { Log (Domestic } \\
\text { Remittances) }\end{array}$ & $\begin{array}{c}\text { Any International } \\
\text { Remittances } \\
\end{array}$ & $\begin{array}{c}\text { Log (International } \\
\text { Remittances) }\end{array}$ \\
\hline \multicolumn{7}{|c|}{ PANEL A: MEN } \\
\hline \multirow[t]{2}{*}{ Treatment Effect } & -0.036 & 0.313 & $-0.068 * *$ & 0.121 & 0.017 & 1.104 \\
\hline & $(0.038)$ & $(0.421)$ & $(0.035)$ & $(0.536)$ & $(0.022)$ & (1.079) \\
\hline \multirow[t]{2}{*}{ Year 2008} & -0.005 & 0.003 & -0.003 & -0.146 & -0.003 & $1.281^{* *}$ \\
\hline & $(0.010)$ & $(0.230)$ & $(0.010)$ & $(0.259)$ & $(0.004)$ & $(0.643)$ \\
\hline \multirow[t]{2}{*}{ Age $70^{+}$} & 0.014 & 0.400 & 0.017 & 0.223 & -0.008 & 0.959 \\
\hline & $(0.022)$ & $(0.275)$ & $(0.022)$ & $(0.349)$ & $(0.010)$ & $(0.654)$ \\
\hline \multirow[t]{2}{*}{ Treated Locality } & -0.026 & 0.027 & -0.018 & 0.115 & -0.009 & -0.079 \\
\hline & $\begin{array}{l}(0.026) \\
-0.027\end{array}$ & $(0.361)$ & $\begin{array}{c}(0.022) \\
0.005\end{array}$ & $(0.437)$ & $(0.013)$ & $(0.758)$ \\
\hline$\left(\text { Age } 70^{+}\right)^{*}($ Treated Locality) & $(0.030)$ & $(0.320)$ & $(0.028)$ & $(0.381)$ & $\begin{array}{l}-0.023 \\
(0.016)\end{array}$ & $(0.740)$ \\
\hline \multirow[t]{2}{*}{ (Age 70+)*(Year 2008) } & -0.015 & -0.412 & -0.021 & -0.298 & 0.002 & -1.205 \\
\hline & $(0.022)$ & $(0.283)$ & $(0.022)$ & $(0.334)$ & $(0.008)$ & $(0.941)$ \\
\hline \multirow[t]{2}{*}{ (Treated Locality)*(Year 2008) } & 0.010 & -0.186 & 0.012 & -0.073 & 0.001 & $-1.630 * *$ \\
\hline & $(0.022)$ & $(0.320)$ & $(0.018)$ & $(0.402)$ & $(0.014)$ & $(0.763)$ \\
\hline Observations & 9,212 & 1,186 & 9,212 & 905 & 9,212 & 325 \\
\hline \multicolumn{7}{|c|}{ PANEL B: WOMEN } \\
\hline \multirow[t]{2}{*}{ Treatment Effect } & $-0.104 * *$ & -0.151 & $-0.098 * *$ & 0.064 & -0.011 & -0.342 \\
\hline & $(0.042)$ & $(0.247)$ & $(0.038)$ & $(0.285)$ & $(0.022)$ & $(0.784)$ \\
\hline \multirow[t]{2}{*}{ Year 2008} & -0.019 & -0.136 & $-0.028^{*}$ & -0.146 & 0.002 & -0.411 \\
\hline & $(0.017)$ & $(0.108)$ & $(0.016)$ & (0.105) & $(0.006)$ & $(0.425)$ \\
\hline \multirow[t]{2}{*}{ Age $70^{+}$} & 0.001 & 0.109 & -0.009 & 0.156 & 0.004 & -0.327 \\
\hline & $(0.022)$ & $(0.170)$ & $(0.021)$ & $(0.181)$ & $(0.009)$ & $(0.464)$ \\
\hline \multirow[t]{2}{*}{ Treated Locality } & 0.056 & -0.006 & 0.016 & 0.133 & 0.035 & 0.197 \\
\hline & $(0.048)$ & $(0.251)$ & $(0.045)$ & $(0.275)$ & $(0.025)$ & $(0.711)$ \\
\hline \multirow[t]{2}{*}{ (Age 70+)*(Treated Locality) } & -0.028 & -0.217 & -0.012 & $-0.400 *$ & -0.017 & 0.182 \\
\hline & $(0.030)$ & $(0.191)$ & $(0.027)$ & $(0.214)$ & $(0.018)$ & $(0.508)$ \\
\hline \multirow[t]{2}{*}{ (Age 70+)*(Year 2008) } & $0.059^{* *}$ & $0.261 *$ & $0.060 * * *$ & 0.228 & 0.003 & 0.269 \\
\hline & $(0.023)$ & $(0.158)$ & $(0.022)$ & $(0.161)$ & $(0.008)$ & $(0.646)$ \\
\hline \multirow[t]{2}{*}{ (Treated Locality)*(Year 2008) } & -0.004 & -0.165 & 0.001 & -0.343 & 0.002 & -0.067 \\
\hline & $(0.031)$ & $(0.212)$ & $(0.026)$ & $(0.250)$ & $(0.018)$ & (0.593) \\
\hline Observations & 10,074 & 2,429 & 10,074 & 2,012 & 10,074 & 530 \\
\hline
\end{tabular}

Notes: All regressions include a constant term as well as the regressors in Table 3 . Robust standard errors (in parentheses) are clustered at the municipal level. ${ }^{* * *} \mathrm{p}<0.01,{ }^{* *} \mathrm{p}<0.05,{ }^{*} \mathrm{p}<0.1$ 
Table 5: Robustness Checks

\begin{tabular}{|c|c|c|c|c|c|c|}
\hline & (1) & (2) & (3) & (4) & (5) & (6) \\
\hline & $\begin{array}{c}\text { Any } \\
\text { Remittances }\end{array}$ & $\begin{array}{c}\text { Log (Total } \\
\text { Remittances) }\end{array}$ & $\begin{array}{l}\text { Any Domestic } \\
\text { Remittances }\end{array}$ & $\begin{array}{c}\text { Log (Domestic } \\
\text { Remittances) }\end{array}$ & $\begin{array}{c}\text { Any International } \\
\text { Remittances }\end{array}$ & $\begin{array}{c}\text { Log (International } \\
\text { Remittances) }\end{array}$ \\
\hline \multicolumn{7}{|c|}{ PANEL A: Placebo test using ENIGH 2004 and 2006} \\
\hline Treatment Effect & $\begin{array}{l}-0.038 \\
(0.028)\end{array}$ & $\begin{array}{c}0.349 \\
(0.214)\end{array}$ & $\begin{array}{l}-0.019 \\
(0.028)\end{array}$ & $\begin{array}{c}0.223 \\
(0.251)\end{array}$ & $\begin{array}{l}-0.013 \\
(0.015)\end{array}$ & $\begin{array}{l}-0.647 \\
(0.579)\end{array}$ \\
\hline Observations & 15739 & 2835 & 15739 & 2337 & 15739 & 621 \\
\hline \multicolumn{7}{|c|}{ PANEL B: Treatment: Localities $<15,000$; Control: Localities $>100,000$} \\
\hline Treatment Effect & $\begin{array}{l}-0.051^{* *} \\
(0.025)\end{array}$ & $\begin{array}{c}0.036 \\
(0.181)\end{array}$ & $\begin{array}{c}-0.067 * * * \\
(0.022)\end{array}$ & $\begin{array}{c}0.149 \\
(0.222)\end{array}$ & $\begin{array}{c}0.008 \\
(0.014)\end{array}$ & $\begin{array}{c}0.134 \\
(0.537)\end{array}$ \\
\hline Observations & 22,127 & 4,230 & 22,127 & 3,368 & 22,127 & 1,045 \\
\hline \multicolumn{7}{|c|}{ PANEL C: Treatment: Localities $<15,000$; Control: Localities $>15,000$} \\
\hline Treatment Effect & $\begin{array}{c}-0.056^{* *} \\
(0.024)\end{array}$ & $\begin{array}{c}0.078 \\
(0.167)\end{array}$ & $\begin{array}{c}-0.062 * * * \\
(0.021)\end{array}$ & $\begin{array}{c}0.210 \\
(0.204)\end{array}$ & $\begin{array}{l}-0.001 \\
(0.014)\end{array}$ & $\begin{array}{c}0.464 \\
(0.431)\end{array}$ \\
\hline Observations & 26,514 & 5,165 & 26,514 & 4,143 & 26,514 & 1,246 \\
\hline \multicolumn{7}{|c|}{ PANEL D: Excluding States with Other Types of Transfer Programs } \\
\hline Treatment Effect & $\begin{array}{c}-0.076^{* *} \\
(0.033)\end{array}$ & $\begin{array}{c}0.082 \\
(0.242)\end{array}$ & $\begin{array}{c}-0.097 * * * \\
(0.029)\end{array}$ & $\begin{array}{l}-0.004 \\
(0.302)\end{array}$ & $\begin{array}{c}0.014 \\
(0.019)\end{array}$ & $\begin{array}{c}0.090 \\
(0.667)\end{array}$ \\
\hline Observations & 13,961 & 2,624 & 13,961 & 2,094 & 13,961 & 639 \\
\hline \multicolumn{7}{|c|}{ PANEL E: Households with at Least One Member 55 Years of Age or Older } \\
\hline Treatment Effect & $\begin{array}{c}-0.127 * * * \\
(0.040)\end{array}$ & $\begin{array}{l}-0.288 \\
(0.223)\end{array}$ & $\begin{array}{c}-0.127^{* * *} \\
(0.040)\end{array}$ & $\begin{array}{l}-0.081 \\
(0.248)\end{array}$ & $\begin{array}{l}-0.024 \\
(0.031)\end{array}$ & $\begin{array}{l}-0.686 \\
(0.448)\end{array}$ \\
\hline Observations & 10,093 & 3,200 & 10,093 & 2,637 & 10,093 & 785 \\
\hline
\end{tabular}

Notes: All regressions include a constant term and municipality fixed effects. Robust standard errors (in parentheses) are clustered at the municipal level. $* * * \mathrm{p}<0.01, * * \mathrm{p}<0.05$, $* \mathrm{p}<0.1$ 
Table 6: OLS Results for Government Transfers and Non-labor Income of individuals 55 Years of Age or Older

\begin{tabular}{|c|c|c|c|c|}
\hline & (1) & (2) & (3) & (4) \\
\hline & Any Government Transfers & Log (Government Transfers) & Any Non-labor Income & Log (Non-labor Income) \\
\hline Treatment Effect & $\begin{array}{c}0.510 * * * \\
(0.033)\end{array}$ & $\begin{array}{l}-0.115 \\
(0.334)\end{array}$ & $\begin{array}{c}\mathbf{0 . 1 7 8} * * * \\
(\mathbf{0 . 0 2 8})\end{array}$ & $\begin{array}{c}0.107 \\
(0.087)\end{array}$ \\
\hline Year 2008 & $\begin{array}{c}0.002 \\
(0.009)\end{array}$ & $\begin{array}{l}-0.169 \\
(0.265)\end{array}$ & $\begin{array}{c}0.009 \\
(0.014)\end{array}$ & $\begin{array}{c}-0.159 * * * \\
(0.048)\end{array}$ \\
\hline Age $70+$ & $\begin{array}{c}0.076^{* *} \\
(0.035)\end{array}$ & $\begin{array}{c}0.195 \\
(0.253)\end{array}$ & $\begin{array}{c}0.081^{* * *} \\
(0.024)\end{array}$ & $\begin{array}{l}-0.069 \\
(0.063)\end{array}$ \\
\hline Treated Locality & $\begin{array}{c}0.019 \\
(0.018)\end{array}$ & $\begin{array}{c}0.065 \\
(0.395)\end{array}$ & $\begin{array}{c}0.104 * * * \\
(0.030)\end{array}$ & $\begin{array}{c}-0.611 * * * \\
(0.122)\end{array}$ \\
\hline (Age 70+)*(Treated Locality) & $\begin{array}{l}-0.063 \\
(0.039)\end{array}$ & $\begin{array}{l}-0.189 \\
(0.313)\end{array}$ & $\begin{array}{c}-0.164 * * * \\
(0.026)\end{array}$ & $\begin{array}{c}0.063 \\
(0.072)\end{array}$ \\
\hline$($ Age $70+) *($ Year 2008) & $\begin{array}{c}0.052 * * \\
(0.026)\end{array}$ & $\begin{array}{c}0.112 \\
(0.263)\end{array}$ & $\begin{array}{c}0.024 \\
(0.019)\end{array}$ & $\begin{array}{c}0.091 \\
(0.059)\end{array}$ \\
\hline (Treated Locality)*(Year 2008) & $\begin{array}{c}0.007 \\
(0.014)\end{array}$ & $\begin{array}{l}0.626^{*} \\
(0.354)\end{array}$ & $\begin{array}{l}-0.008 \\
(0.024)\end{array}$ & $\begin{array}{c}0.184^{* *} \\
(0.076)\end{array}$ \\
\hline Observations & 19,285 & 1,949 & 19,285 & 10,649 \\
\hline
\end{tabular}

Notes: All regressions include a constant term as well as the regressors in Table 3. Robust standard errors (in parentheses) are clustered at the municipal level.

$* * * \mathrm{p}<0.01, * * \mathrm{p}<0.05, * \mathrm{p}<0.1$ 
Appendix

Table A. Descriptive statistics of selected variables for individuals age 70+ before the program (2006)

\begin{tabular}{|c|c|c|c|c|}
\hline \multirow[t]{2}{*}{ Selected Variables } & \multicolumn{2}{|c|}{ In localities $<2,500$} & \multicolumn{2}{|c|}{ In localities $>100,000$} \\
\hline & Mean & SD & Mean & SD \\
\hline \multicolumn{5}{|l|}{ Panel A: Individual-level variables } \\
\hline Received any remittances & 0.32 & 0.47 & 0.25 & 0.43 \\
\hline Received any domestic remittances & 0.25 & 0.43 & 0.23 & 0.42 \\
\hline Received any international remittances & 0.09 & 0.29 & 0.03 & 0.18 \\
\hline Total remittances received & 254 & 1142 & 274 & 1128 \\
\hline Domestic remittances received & 153 & 1008 & 238 & 1071 \\
\hline International remittances received & 101 & 554 & 36 & 334 \\
\hline Total remittances received if positive amount & 769 & 1772 & 1217 & 2561 \\
\hline Domestic remittances received if positive amount & 615 & 1821 & 1178 & 2606 \\
\hline International remittances received if positive amount & 994 & 1338 & 1067 & 1427 \\
\hline Individual non-labor income & 932 & 2424 & 2924 & 7885 \\
\hline \multicolumn{5}{|l|}{ Panel B: Household-level variables } \\
\hline Received any remittances & 0.47 & 0.50 & 0.36 & 0.48 \\
\hline Received any domestic remittances & 0.35 & 0.48 & 0.33 & 0.47 \\
\hline Received any international remittances & 0.16 & 0.37 & 0.05 & 0.21 \\
\hline Total remittances received & 567 & 1745 & 622 & 2120 \\
\hline Domestic remittances received & 294 & 1444 & 532 & 2024 \\
\hline International remittances received & 273 & 1037 & 90 & 616 \\
\hline Total remittances received if positive amount & 894 & 1710 & 1384 & 2499 \\
\hline Domestic remittances received if positive amount & 633 & 1669 & 1296 & 2510 \\
\hline International remittances received if positive amount & 1248 & 1505 & 1407 & 1629 \\
\hline Household size & 3.41 & 2.40 & 3.34 & 2.18 \\
\hline Number of members age $70+$ & 1.27 & 0.46 & 1.22 & 0.43 \\
\hline Per capita income in the household & 902 & 1515 & 2587 & 4180 \\
\hline
\end{tabular}

Sample: Individuals age 70+ from ENIGH 2006. Remittances and income variables are in real pesos per month. The number of individuals is 760 and 947 in localities with less than 2,500 inhabitants and localities with 100,000 or more inhabitants, respectively. 
${ }^{1}$ The program transfer is 500 Mexican pesos per month. To get the equivalent amount in U.S dollars, we used an exchange rate 12.5 pesos per dollar, which was the average in the first six months of 2013.

${ }^{2}$ In the motivation section of the 2007 Rules of Operation of the program, it says that "the Federal Government starts this support program for older adults, with the purpose of improving their income, and as a result, their living conditions”. Please refer to: “Acuerdo por el que se emiten y publican las Reglas de Operación del Programa de Atención a los Adultos Mayores de 70 años y más en zonas rurales para el ejercicio fiscal 2007” published in Diario Oficial de la Federación on February 28th, 2007.

${ }^{3}$ As shown in the first column of Table A in the appendix, the mean total remittances received by individuals with those characteristics was 769 pesos in 2006. In the same year, for this sample of remittance-receiving individuals, the average individual income was 1,349 pesos in 2006 (not shown).

${ }^{4}$ The program has a budget of 18 billion Mexican pesos ( $\$ 1.3$ billion) for 2012, up from 6 billion Mexican pesos in 2007, when it was launched (Guthrie 2012).

${ }^{5}$ As Andreoni $(1989,1990)$ shows, a public transfer would also crowd out private gifts, but to a lesser extent, if donors get utility from the mere act of giving.

${ }^{6}$ These results follow because, under exchange, the amount of private transfers paid to the elderly is $T=p s$, where $p$ is the implicit price of services, and $s$ is the quantity (Cox, 1987).

${ }^{7}$ Please refer to “Informe de la Evaluación Específica de Desempeño 2008”, published by Consejo Nacional de Evaluación de la Política de Desarrollo Social, and available at: www.coneval.gob.mx.

${ }^{8}$ According to the 2012 program rules, individuals age 70 and older were now eligible for the program, regardless of their locality of residence. However, new applicants must have no 
other pension income in order to participate in 70 y Más. This additional requirement, which does not apply to beneficiaries who enrolled before 2012, does not affect our empirical strategy given our focus on the first year of operation of the program.

${ }^{9}$ Seguro Popular is a federal program that expanded public health care services provided to the uninsured population starting in 2004. This program does not contaminate our crowding out results because our data refer to a time period when the program was already in place, and because eligibility for the Seguro Popular is not conditioned on age or locality size. Therefore, any effect of the Seguro Popular on private transfers would also be taking place among individuals in the control groups.

${ }^{10}$ The Oportunidades program pays cash transfers mainly to poor families with school-age children since 1998. Later, a complementary cash transfer for elderly individuals age 70 and older who lived in participating households was added to the program benefits. However, this transfer is about 610 pesos (47 USD) every two months, which is currently less than the transfer from 70 y Más, so it is actually convenient for a person to drop Oportunidades in order to enroll in 70 y Mas. Also note that, until 2011, participation in the 70 y Más program was exclusively conditioned on age and locality of residence, so it covered a broader elderly population than Oportunidades, which has always been means-tested.

${ }^{11}$ Please refer to "Informe del Resultado de la Fiscalización Superior de la Cuenta Pública 2010. Auditoría Financiera y de Cumplimiento. Programa 70 y Más”, available (in Spanish) at: http://www.asf.gob.mx/Trans/Informes/IR2010i/Grupos/Desarrollo_Social/2010_0882.pdf 12 Their evaluation sample covers only seven states: Guerrero, Hidalgo, Michoacán, Puebla, Queretaro, San Luis Potosi and Veracruz, as described in Informe Final de Impacto Parte 1, available at http://www.sedesol.gob.mx/es/SEDESOL/70_y_mas

13 Even though age-eligible individuals in their control localities were delayed program benefits until the end of 2008, when they received the full annual amount in one installment, 
their data on private transfers is from the third round collected in 2009, when these localities were no longer shielded from the program expansion.

${ }^{14}$ Aguila et al. (2011) provide a summary of the rules, coverage and year of implementation of these state programs in Table A.1 of their appendix.

15 The sampling procedure followed for the ENIGH ensures that each round is a representative cross section of Mexican households nationwide.

16 Neither of the two categories of private transfers includes gifts or donations from governmental or non-governmental organizations.

17 This distinction between the extensive and intensive margins is important in the literature. Theoretically, Cox (1987) shows that an increase in the income of the recipient reduces the probability of receiving private transfers sent with altruistic and exchange motives. He also shows that, when private transfers are strictly positive, such income increase has a negative effect on the amount received under the altruistic motive, whereas it could have a positive effect under exchange. Such distinction also matters in the context of voluntary contributions to a public good, as in the empirical work of Brunner (1998).

18 Seniors close to age 70 might respond to the program in anticipation of forthcoming benefits in a few years. To assess that possibility, we repeated the analysis excluding individuals 66 to 69 years of age from our control group. Results, available from the authors, prove robust to the use of this alternative sample.

${ }^{19}$ Ideally, we would like to cluster standard errors at the locality level, but we lack locality identifiers. Nevertheless, given the rapid expansion of the program, it is reasonable to assume that, once the program was implemented in a given municipality, all qualifying localities were incorporated at once. 
${ }^{20}$ At the household level (not shown), it is worth noting that rural households have larger shares of children and elderly members than their urban counterparts, and they are less likely to be female-headed.

${ }^{21}$ The means in Table 2, their differences over time and across groups, and their standard errors are estimated using OLS regressions and all of the observations in the corresponding groups and years, including those who received zero government transfers or remittances.

${ }^{22}$ In our sample, the fraction of age-qualifying men and women who receive any remittances in treated localities in 2006 is 0.27 and 0.35 , respectively.

${ }^{23}$ The mean amount received by age-eligible men and women, who receive any remittances, in treated localities in 2006 is 1166 and 896 pesos per month, respectively.

${ }^{24}$ The positive effect observed for men in column 5 could partly explain why we observe a lower negative and insignificant estimate in column 1, even though they also experience a reduction in domestic remittances due to the program.

${ }^{25}$ Articles about the start of the program in May 2007 can be found in national newspapers like El Universal (http://www.eluniversal.com.mx/notas/422459.html) and La Jornada (http://www.jornada.unam.mx/2007/05/03/index.php?section=politica\&article=013n2pol), and in local ones like El Porvenir (from the city of Monterrey, http://www.elporvenir.com.mx/notas.asp?nota_id=130181).

${ }^{26}$ Vivir Mejor translates as: To Live Better.

${ }^{27}$ Using ENIGH data for 1998-2004, Juarez (2009) also reports that a small fraction of urban individuals receive any international remittances, which is consistent with the fact that migrants to the U.S. come mostly from rural localities.

${ }^{28}$ Based on the information provided by Aguila et al. (2011), the excluded states are Baja California Norte, Sinaloa, Jalisco, Tabasco, Chiapas, Quintana Roo and Yucatán. 
${ }^{29}$ For instance, a state program in Baja California Norte covers individuals age 60 and older in all localities, whereas another state program in Jalisco covers individuals age 70 and older living in localities with more than 30,000 inhabitants -localities that were not incorporated to the 70 y Más federal program until 2012.

${ }^{30}$ Progresa and Procampo are the only two public cash transfers that can be separately identified in the ENIGH data and, therefore, excluded to isolate the increase in overall government transfers due to the 70 y Más program. Nevertheless, results are similar when we include the aforementioned transfers.

${ }^{31}$ We ran the same regressions in Table 6 on a subsample of seniors whose non-labor income is below the mean. For this subsample $(\mathrm{N}=14,487)$, the treatment effects in columns 1 and 3 are very similar to those obtained for the full sample and statistically significant $(0.5$ and 0.18, respectively). Thus, multiplying the effect on government transfer by the corresponding mean for this subsample $(0.5 * 349=175$ pesos $)$ and doing the same for non-labor income (0.18*461=83), yields the result mentioned above. 